Nevada

Environmental

Restoration

Project

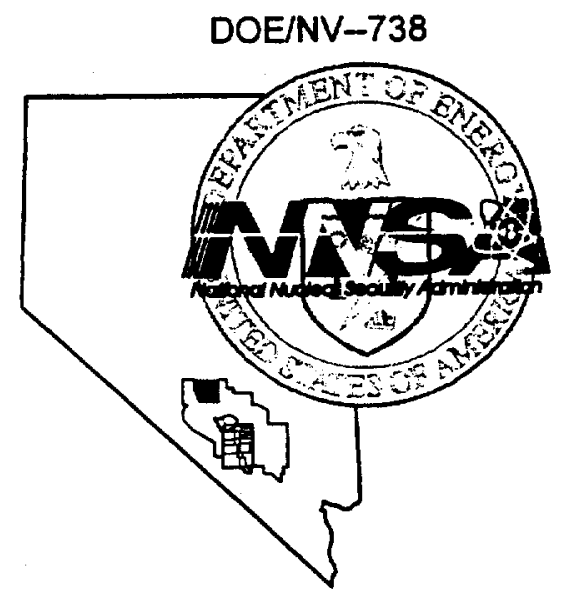

Post-Closure Inspection Report for Corrective Action Unit 427:

Septic Waste Systems 2 and 6 Tonopah Test Range, Nevada Calendar Year 2000

Controlled Copy No::

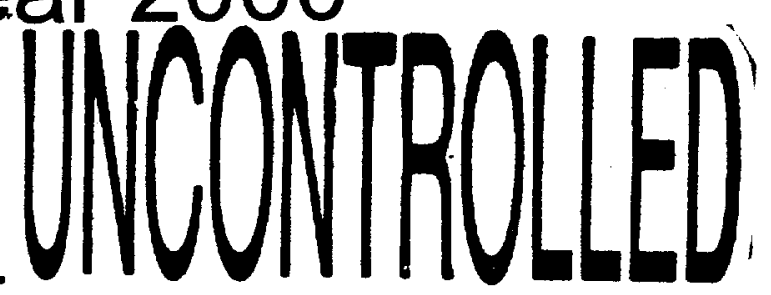

Revision: 0

June 2001

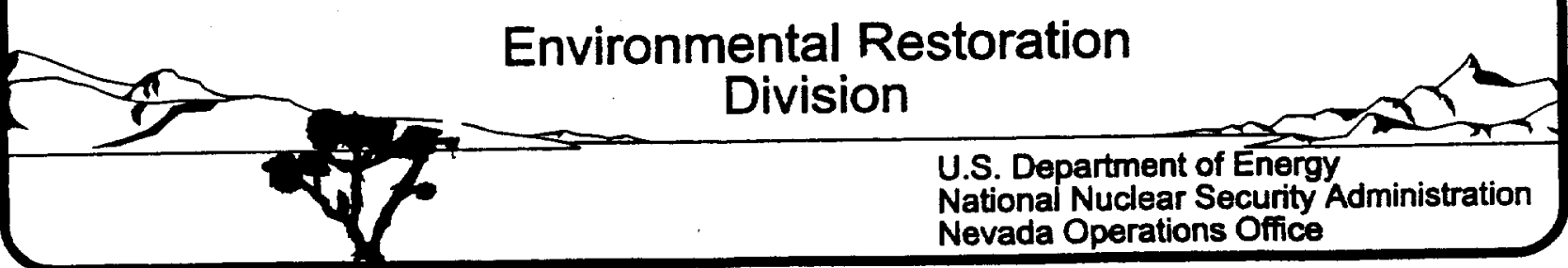




\section{DISCLAIMER STATEMENT}

Reference herein to any specific commercial product, process, or service by trade name, trademark, manufacturer, or otherwise, does not necessarily constitute or imply its endorsement, recommendation, or favoring by the U.S. Government or any agency thereof or its contractors or subcontractors.

\section{AVAILABILITY STATEMENT}

Available for sale to the public from-

U.S. Department of Commerce

National Technical Information Service

5285 Port Royal Road

Springfield, VA 22161-0002

Telephone: 800.553 .6847

Fax: 703.605.6900

E-mail: orders@ntis.fedworld.gov

Online ordering: http://www.ntis.gov/ordering.htm

Available electronically at http://www.doe.gov/bridge

Available for a proces to U.S. Department of Energy and its contractors, in paper, from-

U.S. Departme 'ergy

Office of Scientitic and Technical Information

P.O. Box 62

Oak Ridge, TN 37831-0062

Telephone: 865.576 .8401

Fax: 865.576.5728

E-mail: reports@.adonis.osti.gov 


\title{
POST-CLOSURE INSPECTION REPORT FOR CORRECTIVE ACTION UNIT 427: AREA 3 SEPTIC WASTE SYSTEMS 2 AND 6 TONOPAH TEST RANGE, NEVADA CALENDAR YEAR 2000
}

\author{
Prepared for \\ U. S. Department of Energy \\ National Nuclear Security Administration \\ Nevada Operations Office \\ Work Performed Under Contract No. \\ DE-AC08-96NV11718
}

Controlled Copy No.:

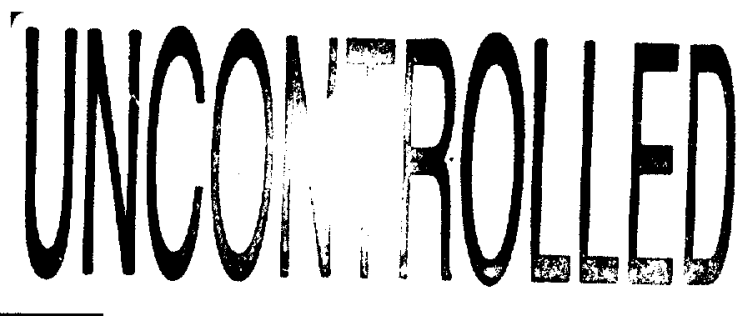

Revision: 0

June 2001 


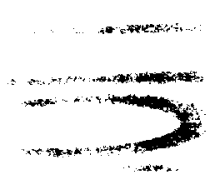

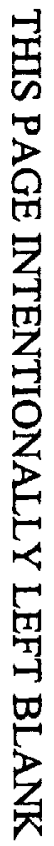

E:
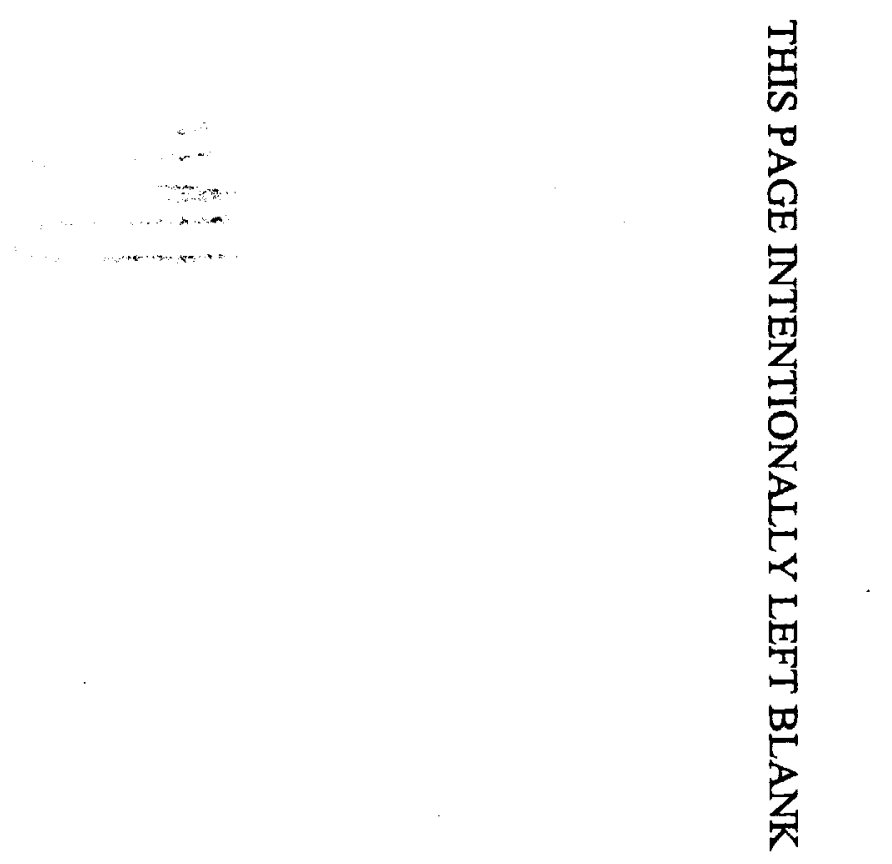
DOE/NV-738

\section{POST-CLOSURE INSPECTION REPORT FOR CORRECTIVE ACTION UNIT 427: AREA 3 SEPTIC WASTE SYSTEMS 2 AND 6 TONOPAH TEST RANGE, NEVADA CALENDAR YEAR 2000}
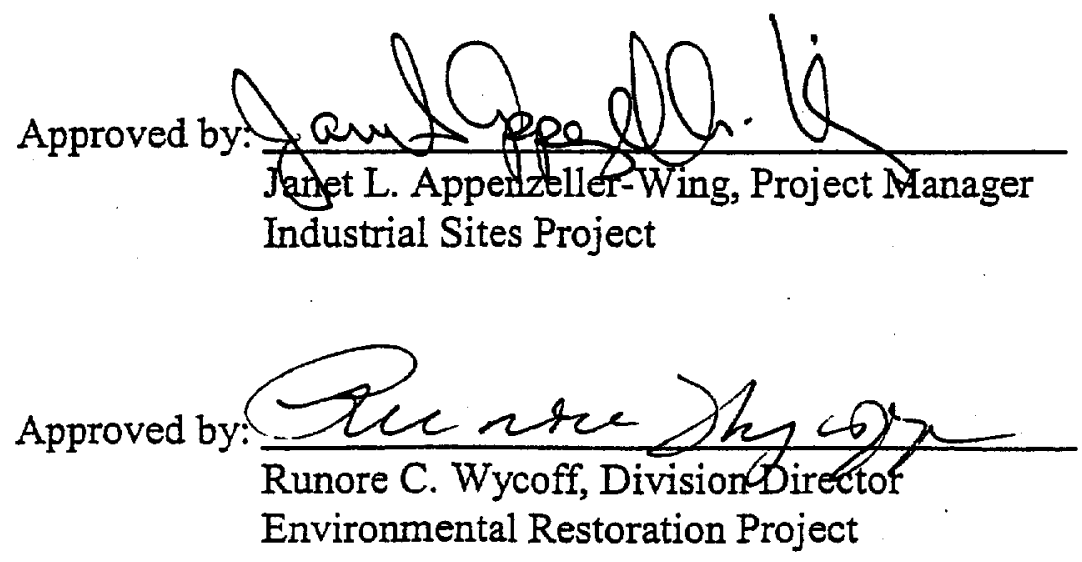

Date: $6 / 21 / 0$ Date: $6 / 21 / 01$ 
THIS PAGE INTENTIONALLY LEFT BLANK 


\section{TABLE OF CONTENTS}

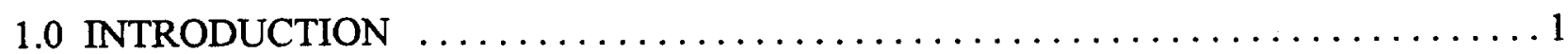

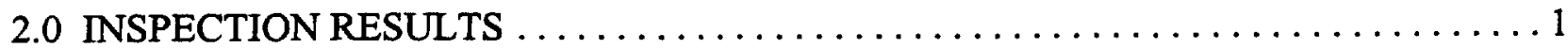

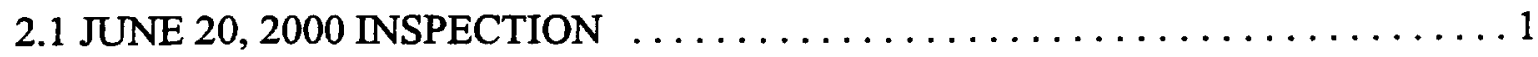

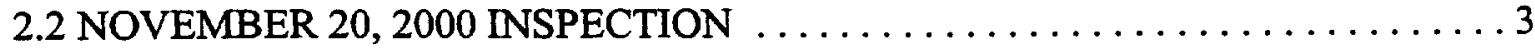

3.0 CONCLUSIONS AND RECOMMENDATIONS $\ldots \ldots \ldots \ldots \ldots \ldots \ldots \ldots \ldots$

\section{FIGURES}

FIGURE 1 - AREA 3 SEPTIC WASTE SYSTEMS 2 AND 6 CAU 427 LOCATION MAP . . 2

\section{APPENDICES}

APPENDIX A - INSPECTION CHECKLISTS

APPENDIX B - FIELD NOTES

APPENDIX C - PHOTOGRAPH LOG AND PHOTOGRAPHS

\section{DRAFT DISTRIBUTION LIST}


THIS PAGE INTENTIONALLY LEFT BLANK 


\subsection{INTRODUCTION}

Post-closure inspection requirements for the Area 3 Septic Waste Systems 2 and 6 (Corrective Action Unit [CAU] 427) (Figure 1) are described in Closure Report for Corrective Action Unit 427. Area 3 Septic Waste Systems 2 and 6, Tonopah Test Range, Nevada, report number DOE/NV-561. The Closure Report (CR) was submitted to the Nevada Division of Environmental Protection (NDEP) on August 16, 1999. The CR (containing the Post-Closure Inspection Plan) was approved by the NDEP on August 27, 1999.

The annual post-closure inspection at CAU 427 consists of the following:

- Verification of the presence of all leachfield and septic tank below-grade markers.

- Verification that the warning signs are in-place, intact, and readable.

- Visual observation of the soil and asphalt cover for indications of subsidence, erosion, and unauthorized use.

The site inspections were conducted on June 20, 2000, and November 21, 2000. All inspections were made after NDEP approval of the CR, and were conducted in accordance with the Post-Closure Inspection Plan in the NDEP-approved CR. No maintenance or repairs were conducted at the site.

This report includes copies of inspection checklists, photographs, recommendations, and conclusions. Copies of the Post-Closure Inspection Checklists are found in Attachment A, a copy of the field notes is found in Attachment B, and a copy of the inspection photographs is found in Attachments C.

\subsection{INSPECTION RESULTS}

\subsection{June 20, 2000 Inspection}

The first annual inspection was conducted on June 20, 2000. All 20 subsurface metal markers were located at the corners of the Leachfield A (4 markers), Leachfield B (4 markers), Pre-1965 Leachfield (4 markers), Abandoned Leachfield (4 markers), and Septic Tank 33-5 ( 4 markers) with a metal detector. The four warning signs were observed to be at the as-built locations on Building 03070T (two signs), Building 0367 (one sign), and east of Building 0367 (one sign). No damage to the signs was observed, and all signs were in good readable condition. The soil and asphalt cover areas are located in high traffic areas. Based upon the traffic and yard maintenance activities, no vegetation was observed in the areas. Additionally, no features were observed to indicate subsidence, erosion, or unauthorized use (cracks, depressions, erosional channeling, etc.) of the closed sites. 
Date: Jume 21, 2001

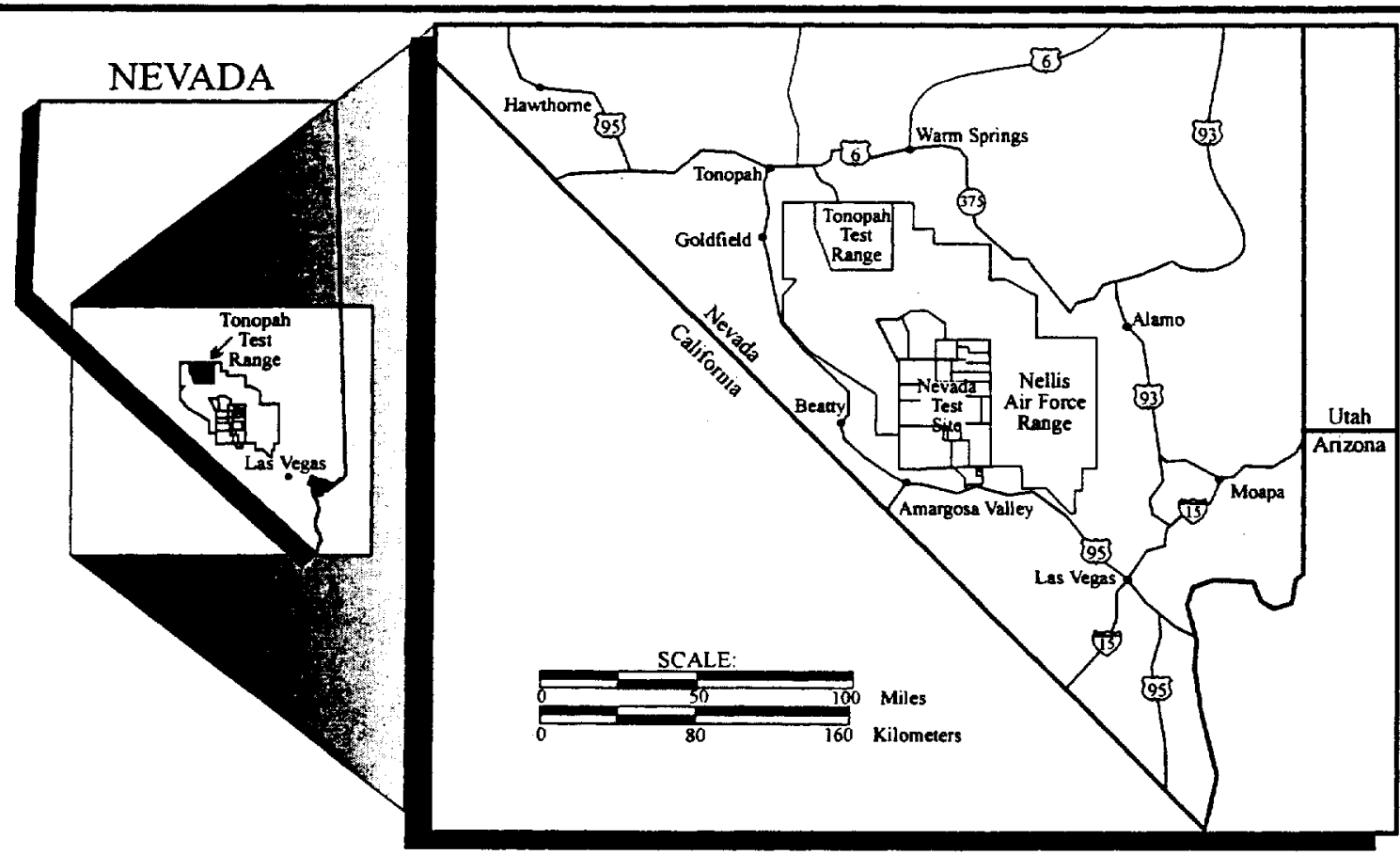

BLM

TONOPAH TEST RANGE

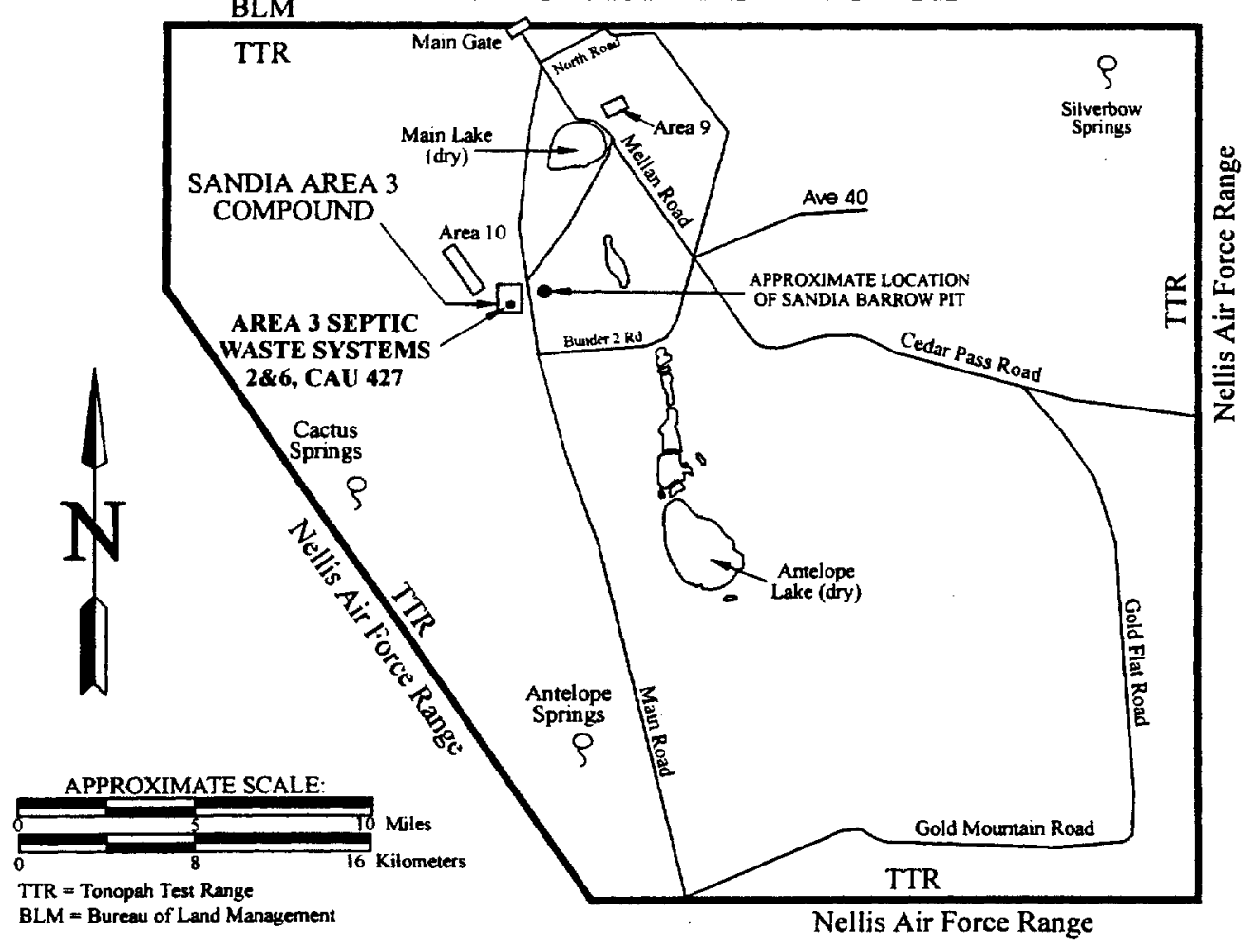

FIGURE 1

AREA 3 SEPTIC WASTE SYSTEMS 2 AND 6 CAU 427 LOCATION MAP 


\subsection{November 20, 2000 Inspection}

The second inspection was made on November 20,2000. All twenty subsurface metal markers were located at the corners of the Leachfield A (4 markers), Leachfield B (4 markers), Pre-1965 Leachfield (4 markers), Abandoned Leachfield (4 markers), and Septic Tank 33-5 ( 4 markers) with a metal detector. The four warning signs were located as shown on the As-built drawing on Building 03070T (two signs), Building 0367 (one sign) and east of Building 0367 (one sign). No damage to the signs was observed, and all signs were in good readable condition. The soil and asphalt cover areas are located in high traffic areas. Based upon the traffic and yard maintenance activities, no vegetation was observed in the areas. A small erosional rill measuring approximately $10-15$ centimeters (4 - 6 inches) deep was observed trending west along side an access road and ending in a parking area. This feature did not affect the integrity of the cover. Additionally, no features were observed to indicate subsidence, erosion, or unauthorized use (cracks, depressions, erosional channeling, etc.) of the closed sites.

\subsection{CONCLUSIONS AND RECOMMENDATIONS}

All signs and subsurface markers were in place. No surface features affecting the integrity of the cover area were observed in the soil and asphalt cover to indicate subsidence, erosion, or unauthorized use.

Inspection of CAU 427 is recommended for the second year as proposed in the CR. Modifications/repairs or inspection frequency are not recommended as a result of the observations conducted. 

APPENDIX A

INSPECTION CHECKLISTS 



\section{POST-CLOSURE INSPECTION CHECKLIST}

CAU 427: Area 3 Septic Waste Systems 2 \& 6, Tonopah Test Range, Nevada

\begin{tabular}{|c|c|}
\hline Date of Last Inspection: N/A Feret Annmal Insp. & Reason for Last Inspection: N/A \\
\hline Responsible Agency: DoE/Nu & Project Manager: Wayne Johnsun \\
\hline \multicolumn{2}{|l|}{ Inspection Date: $6 / 20 / 00$} \\
\hline Inspector: Keuin CampbeU & eoloyist / luth Or \\
\hline
\end{tabular}

\section{A. GENERAL INSTRUCTIONS}

1. All checklist items must be completed and detailed comments made to document the results of the site inspection. The completed checklist is part of the field record of the inspection. Additional pages should be used as necessary so a complete record is made. Attach the additional pages and number all pages upon completion of the inspection.

3. Any checklist line item marked by an inspector in a SHADED BOX, must be fully explained or an

- appropriate reference to previous reports provided. The purpose of this requirement is to provide a written explanation of inspector observations and the inspector's rationale for conclusions and recommendations. Explanations are to be placed on additional attachments and cross-referenced appropriately. Explanations, in addition to the narrative, will take the form of sketches, measurements, and/or annotated site maps.

4. The site inspection is a walking inspection of the entire site including the perimeter and sufficient transects to be able to inspect the entire surface and all features specifically described in this checklist.

5. A standard set of color photographs ( $35 \mathrm{~mm}$, digital, or equivalent) are required to document reportable changes in site conditions between inspections. In addition, all anomalous features or new features (such as changes in adjacent area land use) are to be photographed. A photo log entry will be made for each photograph taken and submitted with the checklist referencing it.

6. This unit will be inspected annually with formal reporting to the Nevada Division of Environmental Protection before completion of the fiscal year in which the inspection occurred. The annual report will include: a narrative summary including recommendations and conclusions; this inspection checklist; inspection field notes; a maintenance record; and photo log (when reportable changes in site conditions are noted).

\begin{tabular}{||l|l|l|l||}
\hline B. PREPARATION (To be completed prior to & YES & NO & EXPLANATION \\
\hline 1. Site as-built plans and site base map reviewed. & $\checkmark$ & & \\
\hline $\begin{array}{l}\text { 2. Previous inspection reports reviewed. } \\
\text { a. Were anomalies or trends detected on previous } \\
\text { inspections? }\end{array}$ & & $\checkmark$ & Thes was first inspection \\
\cline { 2 - 5 }
\end{tabular}




\section{POST-CLOSURE INSPECTION CHECKLIST}

pg zofy

CAU 427: Area 3 Septic Waste Svstems 2 \& 6, Tonopah Test Range, Nevada

B. PREPARATION (To be completed prior to site visit)

2. b. Was maintenance performed?

3. Site maintenance and repair records reviewed.

a. Has site repair resulted in a change from asbuilt conditions?

b. Are revised as-builts available that reflect repair changes?

C. SITE INSPECTION (To be completed during inspection)

\begin{tabular}{|c|c|c|}
\hline YES & NO & EXPLANATION \\
\hline & 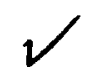 & \\
\hline & & First Anaual Inspection \\
\hline & $\nu$ & $\mu_{0}$ repairs madefrejaired \\
\hline & $\swarrow$ & Fivist Annual Inspectivin \\
\hline YES & NO & EXPLANATION \\
\hline
\end{tabular}

1. Adjacent off-site features.

a. Have there been any changes in use of adjacent areas?

b. Change in surrounding vegetation?

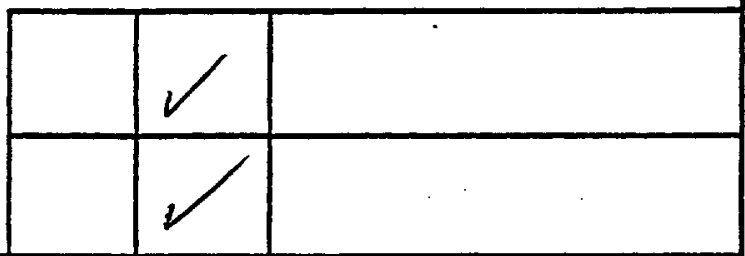

2. Security, signs.

a. Displacement of fences, site markers, boundary markers, or monuments? (disturbed by man or natural processes?).

b. Have any signs been damaged or removed? (Number of signs replaced:

c. Were all subsurface markers detected? (i.e. using a magnatometer or equivalent)

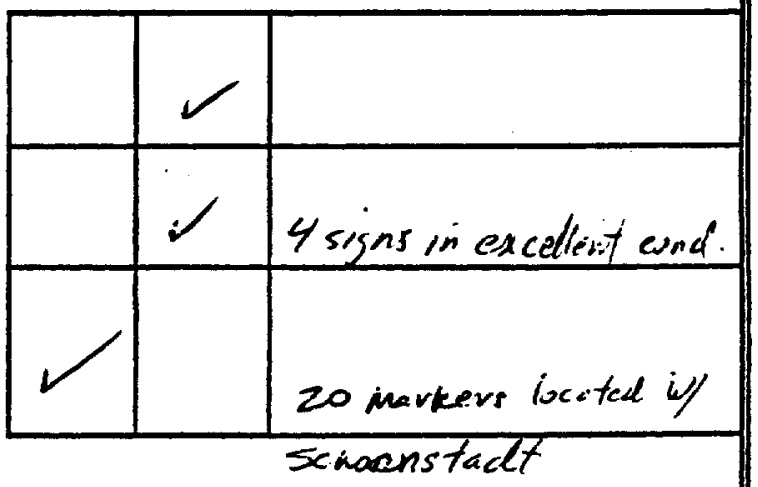




\section{POST-CLOSURE INSPECTION CHECKLIST}

\section{CAU 427: Area 3 Septic Waste Svstems 2 \& 6. Tonopah Test Range. Nevada}

3. Soil/asphalt cover.

a. Is there evidence of settling?

b. Is there cracking?

c. Is there evidence of erosion near the use restriction boundaries?

d. Is there evidence of animal burrowing?

f. Is there vegetation?

g. Do natural processes threaten to integrity of any cover or site marker?

$h$. Is there evidence suggesting unauthorized excavations have taken place?

h. Other?

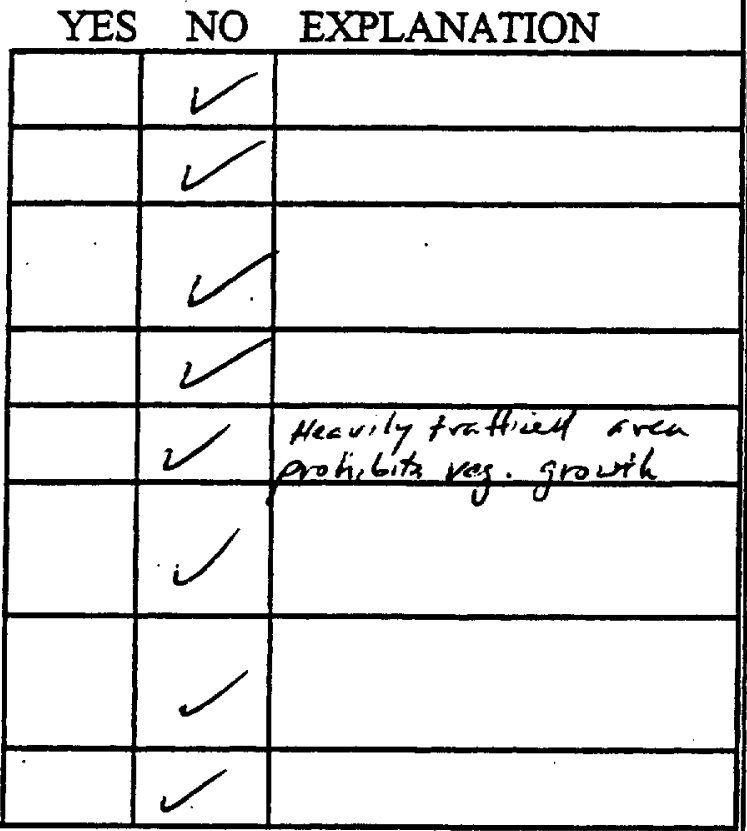

4. Photo Documentation

a. Has a photo log been prepared?

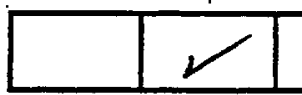

c. Number of photos taken ( 6$)$

\section{FIELD CONCLUSIONS}

1. Is there an imminent hazard to the integrity of the unit? (Immediate report required)

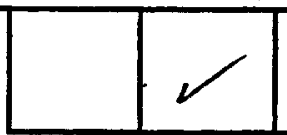

Person/Agency to whom report made:

2. Are more frequent inspections required?

3. Are existing maintenance/repair actions satisfactory?

4. Is other maintenance/repair necessary?

5. Rationale for field conclusions: The vativial for the concluesions a re boset on observations made that indicate thene is no change to the sith use and suifare cunclitions 


\begin{tabular}{|c|c|}
\hline \multicolumn{2}{|c|}{$\begin{array}{l}\text { POST-CLOSURE INSPECTION CHECKLIST } \\
\text { CAU 427: Area 3 Septic Waste Svstems 2 \& 6. Tonopah Test Range. Nevada }\end{array}$} \\
\hline \multicolumn{2}{|l|}{ E. CERTIFICATION } \\
\hline \multicolumn{2}{|c|}{ 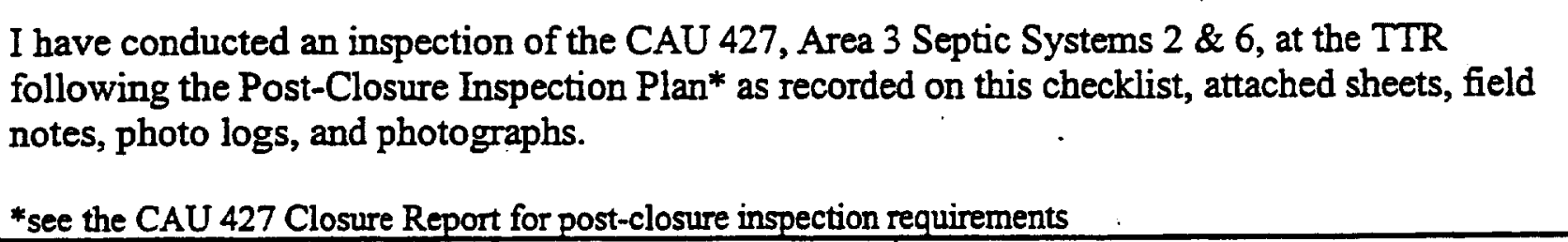 } \\
\hline Chief Inspector's Signature: $\mathscr{L}$ Camplill & Printed Name: Kevin b. Camphell \\
\hline Title: Geolugist / Hydoologist & Date: $6 / 20 / 00$ \\
\hline
\end{tabular}




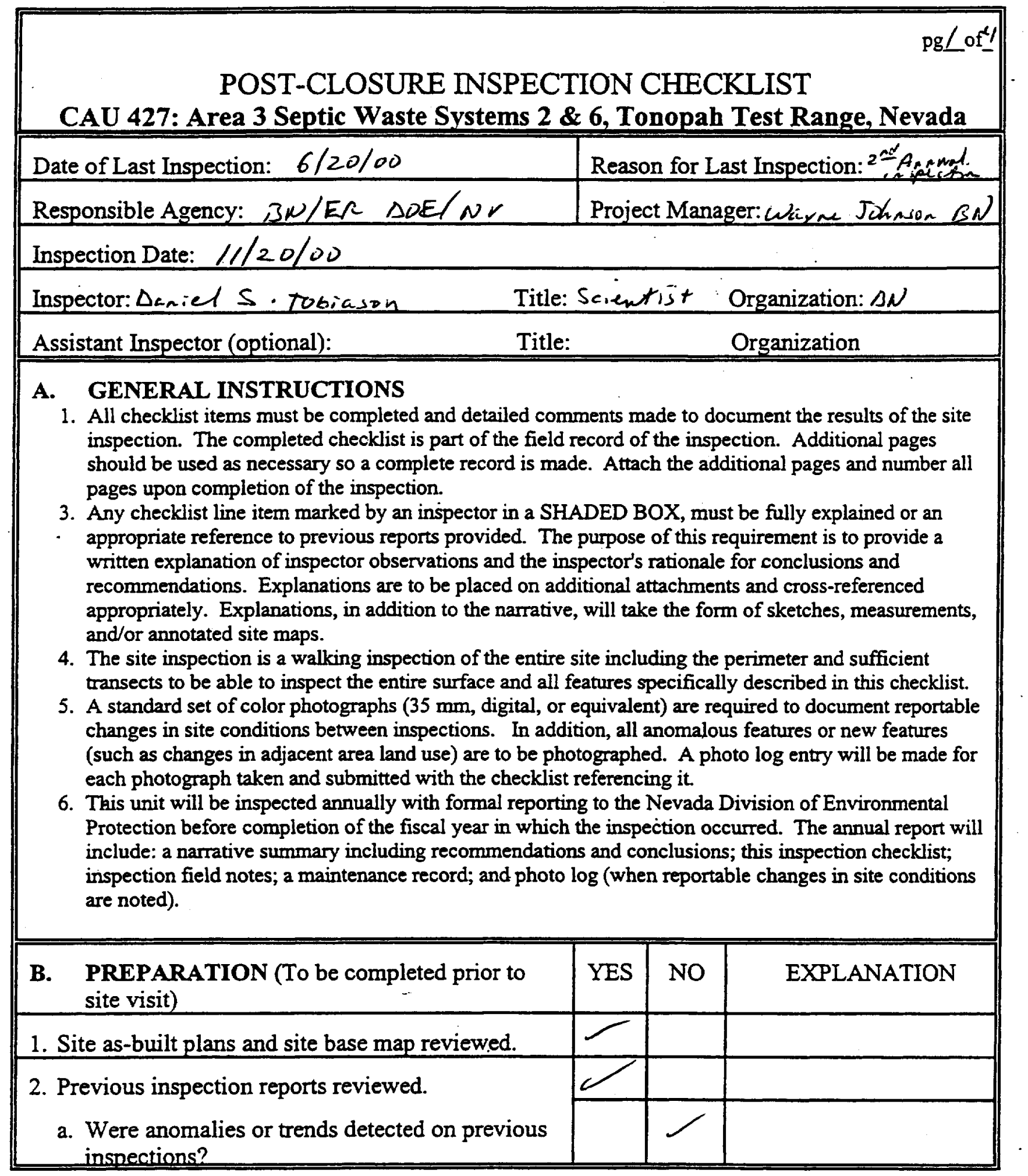




\section{POST-CLOSURE INSPECTION CHECKLIST}

CAU 427: Area 3 Septic Waste Systems 2 \& 6, Tonopah Test Range, Nevada

B. PREPARATION (To be completed prior to site visit)

2. b. Was maintenance performed?

3. Site maintenance and repair records reviewed.

a. Has site repair resulted in a change from asbuilt conditions?

b. Are revised as-builts available that reflect repair changes?

C. SITE INSPECTION (To be completed during inspection)

\begin{tabular}{|c|c|c|}
\hline YES & No & EXPLANATION \\
\hline$\cdots$ & & \\
\hline & & $\begin{array}{l}\text { Now repoired tius } \\
\text { No Reods }\end{array}$ \\
\hline & & NIKG \\
\hline & & $N / R$ \\
\hline YES & NO & EXPLANATION \\
\hline
\end{tabular}

1. Adjacent off-site features.

a. Have there been any changes in use of adjacent areas?

b. Change in surrounding vegetation?

2. Security, signs.

a. Displacement of fences, site markers, boundary markers, or monuments? (disturbed by man or natural processes?)

b. Have any signs been damaged or removed? Number of signs replaced: $\phi \quad)$

c. Were all subsurface markers detected? (i.e. using a magnatometer or equivalent)

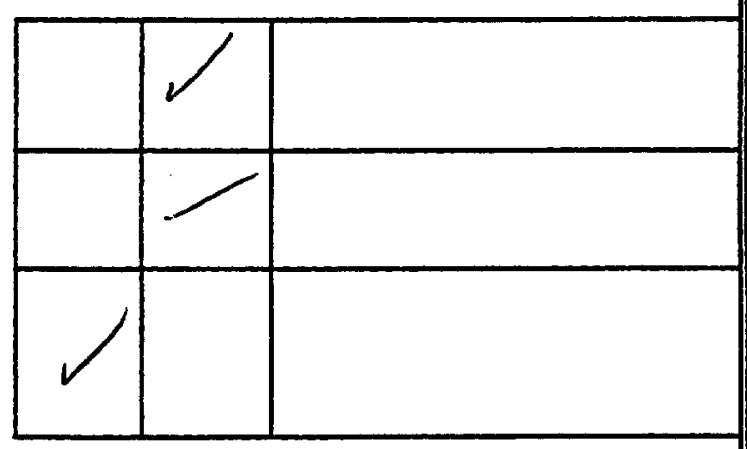




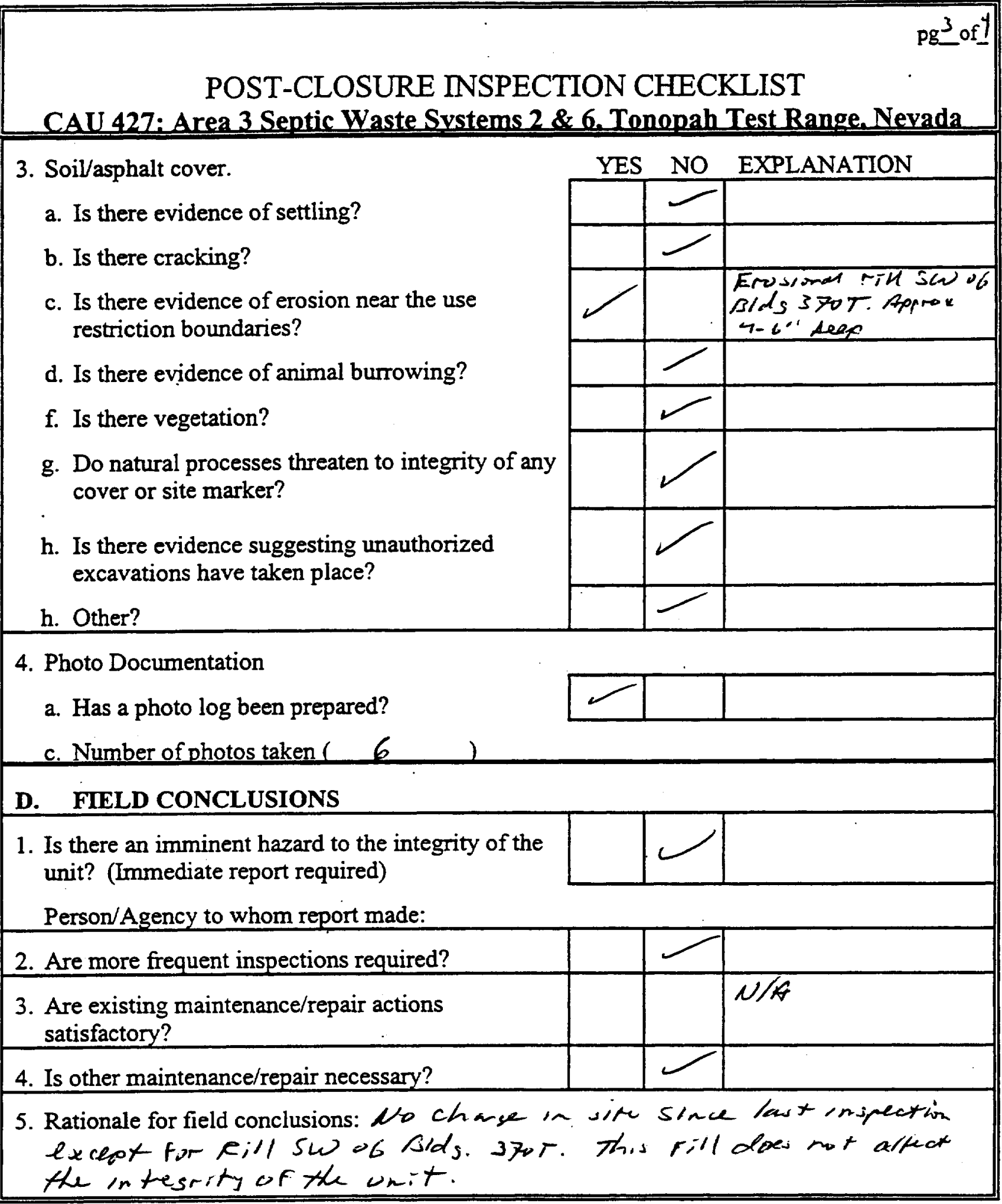




\begin{tabular}{|c|c|}
\hline \multicolumn{2}{|c|}{$\begin{array}{l}\text { POST-CLOSURE INSPECTION CHECKLIST } \\
\text { CAU 427: Area 3 Septic Waste Systems 2 \& 6. Tonopah Test Range, Nevada }\end{array}$} \\
\hline E. CERTIFICATION & \\
\hline $\begin{array}{l}\text { I have conducted an inspectio } \\
\text { following the Post-Closure In } \\
\text { notes, photo logs, and photog } \\
\text { *see the CAU } 427 \text { Closure Repor }\end{array}$ & $\begin{array}{l}\text { Septic Systems } 2 \& 6 \text {, at the TTR } \\
\text { d on this checklist, attached sheets, fieid } \\
\text { equirements }\end{array}$ \\
\hline Chief Inspector's Signature: & Printed Name:Sanied s. Tobiasid \\
\hline Title: Scientist & Date: $19 / 20 / \infty$ \\
\hline
\end{tabular}


APPENDIX B

FIELD NOTES 
$\mathbf{a}$

a

a

$n$

a

a

-

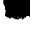

THIS PAGE INTENTIONALLY LEFT BLANK

a 
IE CAusz7 Post Closure Inspedion PROJECT NO.

continued from Page N/A $\quad 6 / 20 / 00$

BOOK NO.

11

Inspection of Cou 427. Area 3 TTR. - Fint Annoul Inspection.

- smive on site with C. Blachluren 9 luesting house. Clein these all plotograflis. 10 digital and $10-35 \mathrm{~mm}$.

- No regetation present due to heary foot and vehide tatic.

ZAll can siguns pstown on As-binits parent and in excelleit condition 4 signs toth. Symin on bulbling $370 \mathrm{~T}$ and 367

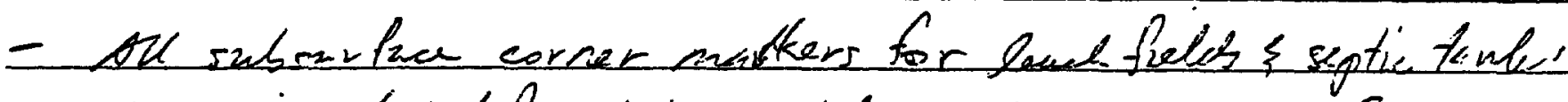

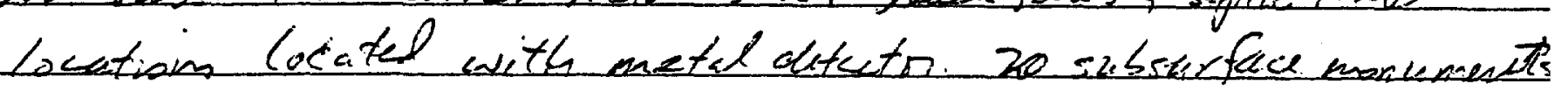
present

2 Combled coustz poot closure inspection.

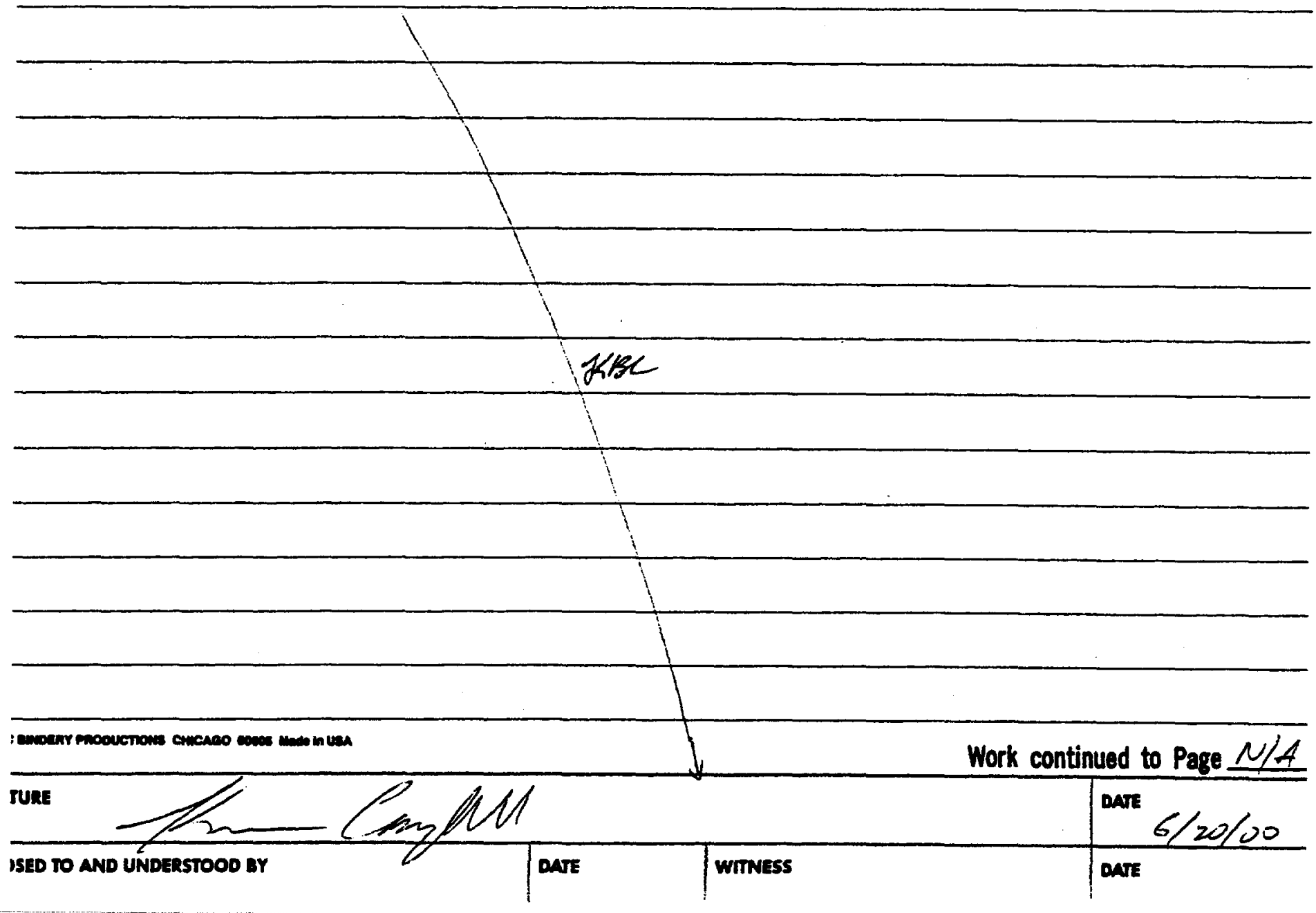


TITLE

Work continued from Page $\underline{\lambda} \bar{\tau}$
PROJECT NO.

BOOK NO.

TTR COST-CLOSURE /NSPECTONS, CONTNUES

ONSAP, NOVEMBER 20,2000

CLEAR, CACM, DOCL (OOB)

I5 INSPECTON OF CAYUYZF, AREA 3 TTR. SECOND FNNUAS INSFECTION

AL SIGNS AS SMOWN OD AS-BULT DERWINGS ARE RRESENT AND ID EXCECCENT CONACTINON.

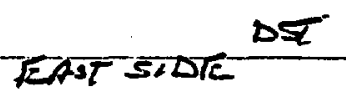
EATT $\$ \triangle D C D T$ ONE SHGN POSTES IN FRONT OF BLAG O367" MUEAR SEPTIC TANK 3TH, RND ONR SION ON WEST UDRLC of BLAG 0367.

ONESGN ERCH ON THE SOUTH AMS WEST WACES of BuILING O370T.

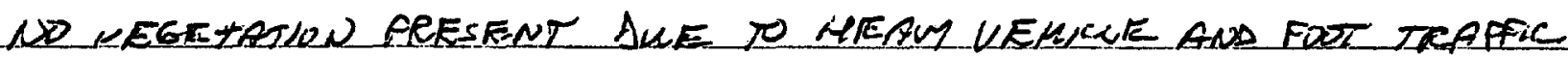

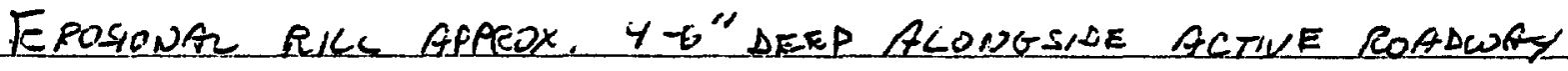
SOUTHCF BIDG. O370T ZILL ECTENDS TO THE WEST INTO THE

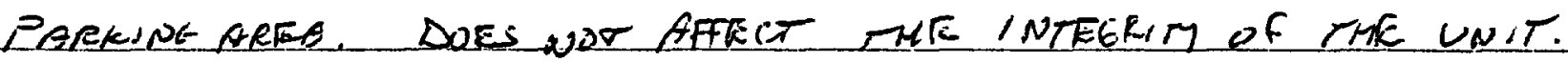

LOCGTES 20 SUSWRFGCE SURVEY MARKERS WHNH LDENTEY THE CORNERS OF THE CEACHEIESAS ANA SEPTHE TANNS. MARAER WTERE LOCATEO USLOL A META DRLECTOR.

2 FINISH CRM YZZ SNSFECTION

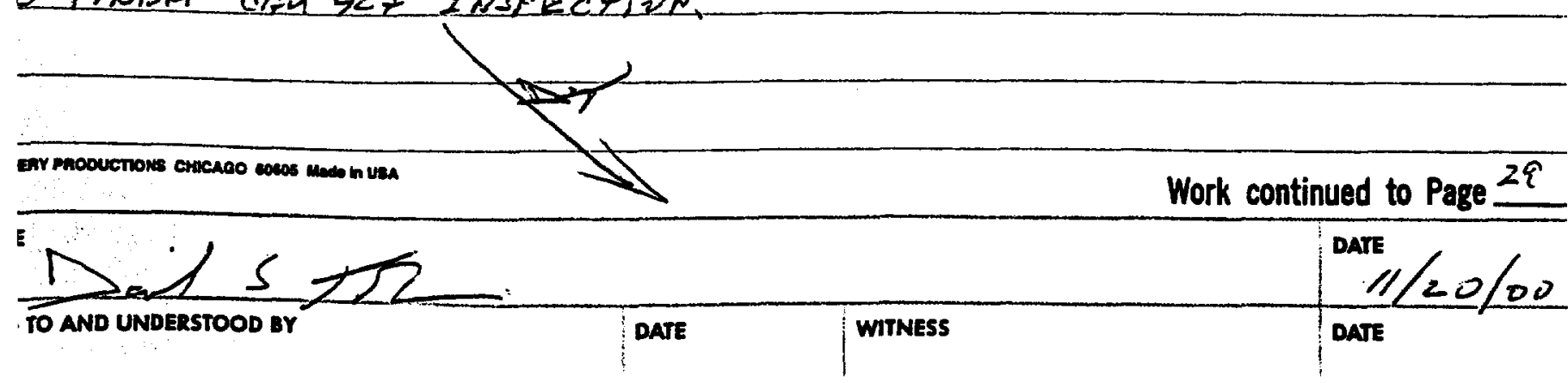


APPENDIX C

\section{PHOTOGRAPH LOG AND PHOTOGRAPHS}


THIS PAGE INTENTIONALLY LEFT BLANK 


\section{PHOTOGRAPH LOG}

\begin{tabular}{|c|c|c|}
\hline $\begin{array}{c}\text { PHOTO } \\
\text { NUMBER } \\
\end{array}$ & DATE & DESCRIPTION \\
\hline 1 & $6 / 20 / 2000$ & $\begin{array}{l}\text { View north over Septic Tank } 33-5 \text { (central area of photograph). } \\
\text { Warning sign on west side of septic tank can be seen at the left } \\
\text { of the photograph. }\end{array}$ \\
\hline 2 & $6 / 20 / 2000$ & $\begin{array}{l}\text { View to southwest across Pre-1965 Leachfield. Person standing } \\
\text { in central area of photograph is in the approximate location of } \\
\text { Septic Tank } 33-4 \text {. The south end of Leachfield A, Leachfield B, } \\
\text { and Abandoned Leachfield are located in the bottom right } \\
\text { quarter of the photograph. }\end{array}$ \\
\hline 3 & $6 / 20 / 2000$ & $\begin{array}{l}\text { View to southeast across Pre-1965 Leachfield. Warning sign on } \\
\text { the west side of Building } 0367 \text { is visible in the center of the } \\
\text { photograph. }\end{array}$ \\
\hline 4 & $6 / 20 / 2000$ & $\begin{array}{l}\text { View to northwest of Leachfield B and Abandoned Leachfield. } \\
\text { Person in photograph is standing at the approximate northwest } \\
\text { boundary of Leachfield B and Abandoned Leachfield. Warning } \\
\text { sign on south side of Building 0370T can be seen in the upper } \\
\text { right corner of the photograph. The south end of Leachfield A is } \\
\text { in the lower right quarter of the photograph. }\end{array}$ \\
\hline 5 & $6 / 20 / 2000$ & $\begin{array}{l}\text { View to southeast of Abandoned Leachfield and Leachfield B. } \\
\text { Person in photograph is standing at the approximate southeast } \\
\text { boundary of Abandoned Leachfield, Leachfield A, and } \\
\text { Leachfield B. Warning sign on west side of Building } 0370 \mathrm{~T} \text { is } \\
\text { visible on building on the left side of the photograph. }\end{array}$ \\
\hline 6 & $6 / 20 / 2000$ & $\begin{array}{l}\text { View to south from North side of Building } 0370 \mathrm{~T} \text {. Person in } \\
\text { photograph is standing at approximate northern boundary of } \\
\text { Leachfield A. }\end{array}$ \\
\hline 7 & $11 / 20 / 2000$ & View north of Septic Tank 33-5 area. Warning sign visible. \\
\hline 8 & $11 / 20 / 2000$ & $\begin{array}{l}\text { View southwest of Pre-1965 Leachfield and location of septic } \\
\text { tanks 33-4 and 33-6. }\end{array}$ \\
\hline 9 & $11 / 20 / 2000$ & $\begin{array}{l}\text { View east of south end of Pre-1965 Leachfield and septic tank } \\
33-4 \text {. Warning sign on Building } 0367 \text { visible. }\end{array}$ \\
\hline 10 & $11 / 20 / 2000$ & $\begin{array}{l}\text { View northwest of Abandoned Leachfield and Leachfield B. } \\
\text { Small erosion rill evident on the south side of leachfields. } \\
\text { Warning sign on south side of Building } 0370 \mathrm{~T} \text { visible. }\end{array}$ \\
\hline
\end{tabular}


Date: June 21, 2001

\begin{tabular}{|c|c|l||}
\hline $\begin{array}{c}\text { PHOTO } \\
\text { NUMBER }\end{array}$ & DATE & \multicolumn{1}{c||}{ DESCRIPTION } \\
\hline \hline 11 & $11 / 20 / 2000$ & $\begin{array}{l}\text { View southeast of Abandoned Leachfield and Leachfield B. } \\
\text { Erosion rill south of Abandoned Leachfield visible. Warning } \\
\text { sign on west side of Building 0370T visible. }\end{array}$ \\
\hline $12 \cdot$ & $11 / 20 / 2000$ & View south looking at building atop Leachfield A. \\
\hline
\end{tabular}




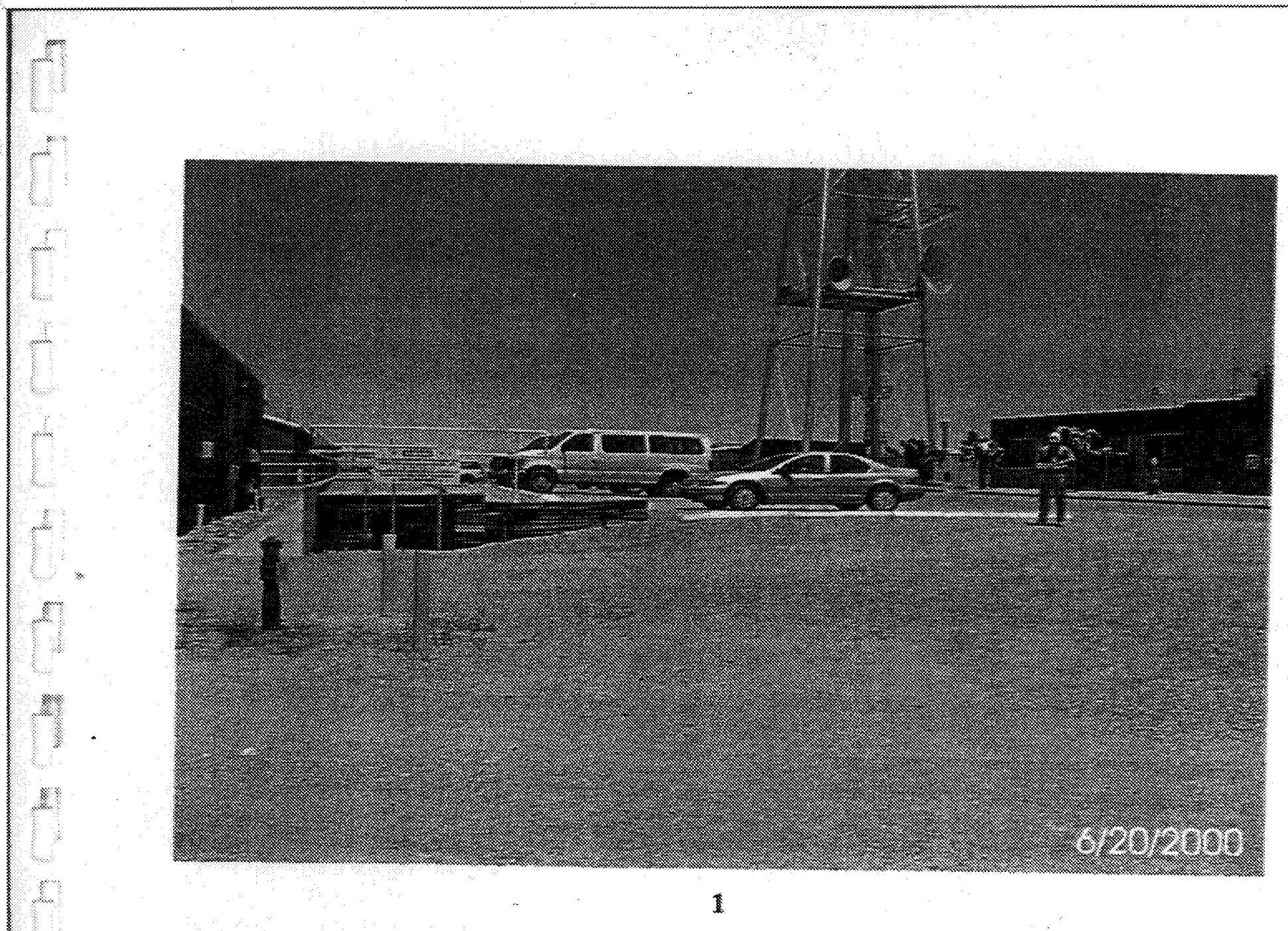




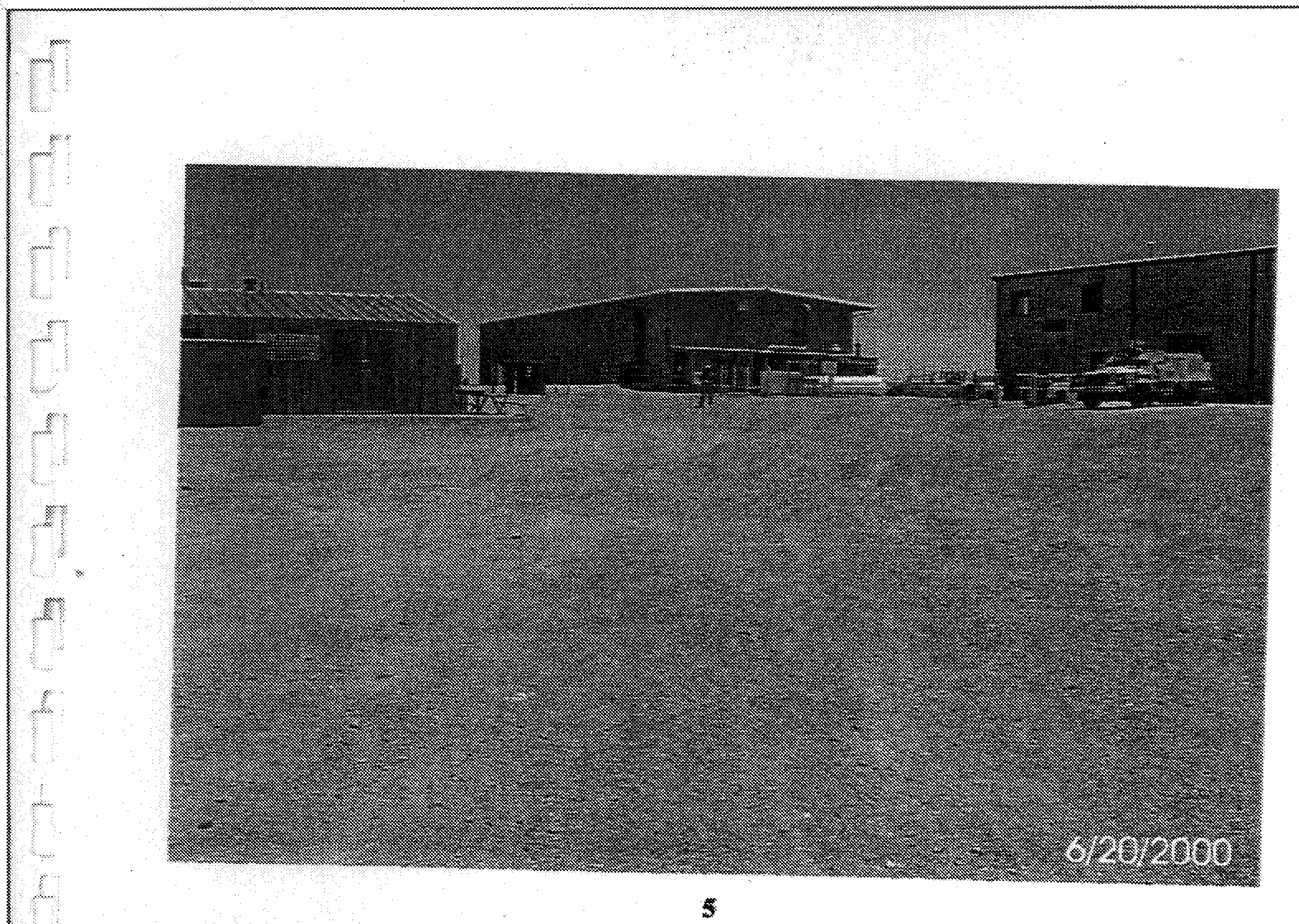

4

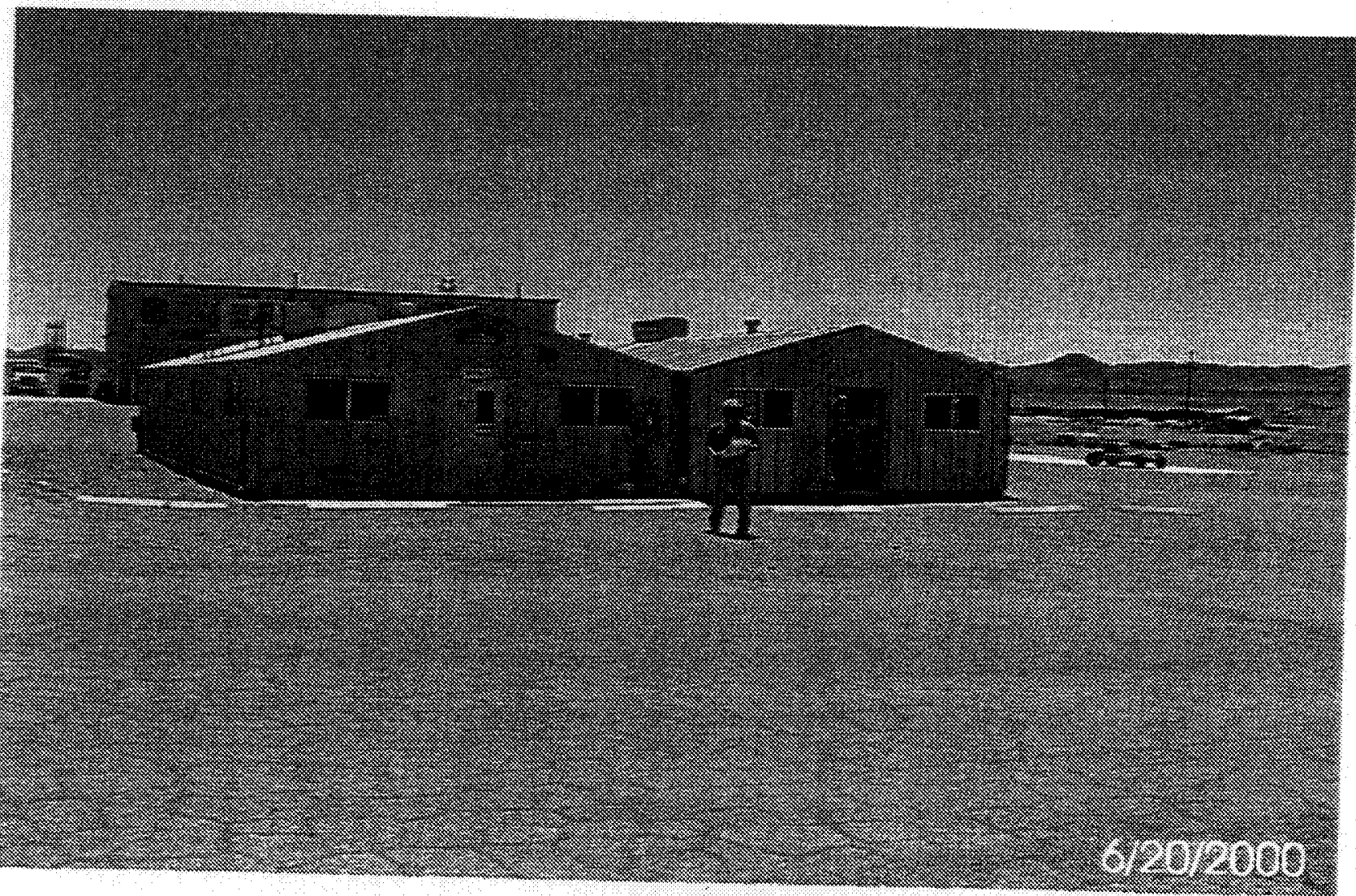



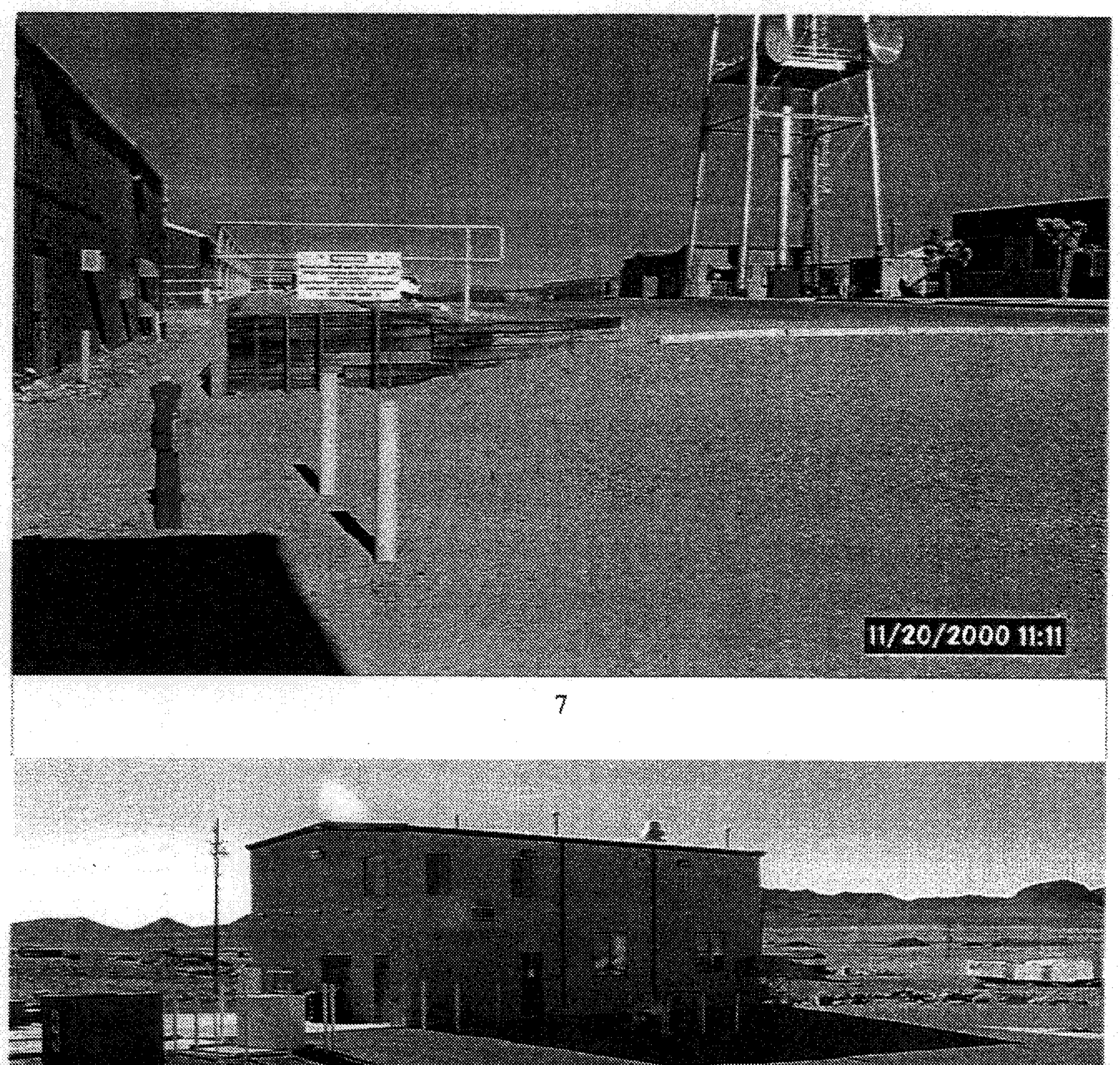


\section{DISTRIBUTION LIST}

*Provide copy of initial distribution of Revision 0 ; remainder of list gets Revision 0 if approved without changes. The entire list receives Revision 1, if issued.

\section{Nevada Department of Environmental Protection}

Paul Liebendorfer

Bureau of Federal Facilities

Division of Environmental Protection

333 W. Nye Lane, Room 13B

Carson City, NV 89706-0866

Mike McKinnon, Las Vegas Office

Bureau of Federal Facilities

Division of Environmental Protection

555 E. Washington, Suite 4300

Las Vegas, NV 89010-1043

\section{U.S. Department of Energy}

Janet Appenzeller-Wing

Environmental Restoration Division

U.S. Department of Energy

National Nuclear Security Administration

Nevada Operations Office

P.O. Box $98518 \mathrm{M} / \mathrm{S} 505$

Las Vegas, NV 89193-8518

Kevin Cabble

Environmental Restoration Division

U.S. Department of Energy

National Nuclear Security Administration

Nevada Operations Office

P.O. Box $98518 \mathrm{M} / \mathrm{S} 505$

Las Vegas, NV 89193-8518

Sabrina Lawrence

Environmental Restoration Division

U.S. Department of Energy

National Nuclear Security Administration

Nevada Operations Office

P.O. Box $98518 \mathrm{M} / \mathrm{S} 505$

Las Vegas, NV 89193-8518
2 (Controlled)*

1 (Controlled)*
1 (Uncontrolled)*

1 (Uncontrolled)*

1 (Controlled)* 


\section{DISTRIBUTION LIST (Continued)}

\section{U.S. Department of Energy (continued)}

U.S. Department of Energy

Office of Scientific and Technical Information

175 Oak Ridge Turnpike

P.O. Box 62

Oak Ridge, TN 37831-0062

Manager, Southern Nevada

FFACO Public Reading Room

P.O. Box $98521 \mathrm{M} / \mathrm{S}$ NLV040

Las Vegas, NV 89193-8521

Manager, Northern Nevada

FFACO Public Reading Room

Nevada State Library and Archives Federal Publications

100 North Stewart Street

Carson City, NV 89701-4285

Technical Information Resource Center

U.S. Department of Energy

National Nuclear Security Administration

Nevada Operations Office

P.O. Box $98521 \mathrm{M} / \mathrm{S} 505$

Las Vegas, NV 89193-8521
1 (Uncontrolled, electronic copy

1 (Controlled \&

1 Uncontrolled)

1 (Uncontrolled)

\section{Bechtel Nevada}

Correspondence Control

Bechtel Nevada

1 (Uncontrolled)*

P.O. Box $98521 \mathrm{M} / \mathrm{S}$ NLV008

Las Vegas, NV 89193-8521

Environmental Management Library

1 (Uncontrolled)*

Bechtel Nevada

P.O. Box 98521 N/S NLV080

Las Vegas, NV 89193-8521

Kevin Campbell

1 (Uncontrolled)*

Bechtel Nevada

P.O. Box $98521 \mathrm{M} / \mathrm{S}$ NTS306

Las Vegas, NV 89193-8521 


\section{DISTRIBUTION LIST (Continued)}

\section{Bechtel Nevada (continued)}

Ann Heidema

1 (Uncontrolled)

Bechtel Nevada

P.O. Box $98521 \mathrm{M} / \mathrm{S}$ NLV022

Las Vegas, NV 89193-8521

Ronald Jackson

1 (Uncontrolled)*

Bechtel Nevada

P.O. Box $98521 \mathrm{M} / \mathrm{S}$ NTS306

Las Vegas, NV 89193-8521

Wayne Johnson

1 (Uncontrolled)*

Bechtel Nevada

P.O. Box $98521 \mathrm{M} / \mathrm{S}$ NTS306

Las Vegas, NV 89193-8521

Steve Nacht

1 (Uncontrolled)*

Bechtel Nevada

P.O. Box $98521 \mathrm{M} / \mathrm{S}$ NTS306

Las Vegas, NV 89193-8521

\section{IT Corporation}

Lynn Kidman

1 (Uncontrolled)*

IT Corporation

P.O. Box $93838 \mathrm{M} / \mathrm{S} 439$

Las Vegas, NV 89193-8521

IT FFACO Support Office

1 (Controlled)

IT Corporation

P.O. Box $93838 \mathrm{M} / \mathrm{S} 439$

Las Vegas, NV 89193-8521 